\title{
Dansk fodbolds udvikling fra omkring 1950 til indførelsen af betalt fodbold i 1978
}

\author{
af Helge Nørregård
}

\section{Indledning}

Artiklen er et sammenkog - og uddrag af ét af de centrale afsnit fra mit samfundsfagsspeciale fra 1980: „Fodbold og samfund - udvikling, professionalisering". Afsnittet har jeg udvalgt efter aftale med redaktionsudvalget, fordi det angiver en udvikling, som oftest har været overset $\mathrm{i}$ forbindelse med indførelsen af betalt fodbold i Danmark.

Udgangspunktet var en hypotese om at fodbolden i denne periode havde bevæget sig fra leglignende aktivitet og hen mod mere arbejdslignende former - nærmere bestemt at det fornøjelige/aktiviteten for aktivitetens egen skyld/det kvalitative/den mindre faste struktur var gået tilbage til fordel for det mere alvorlige/kvantitative/rationelt forberedende/fast strukturerede inden for aktiviteten.

Problemstillingen var interessant af flere grunde. For det første var den ind i mellem hårde, trælse men nødvendige træning ét af de væsentlige argumenter for opgivelsen af amatøridealet inden for dansk fodbold. I DBU's pjece fra 78, ,Betalt fodbold - hvorfor nu det?“ hed det f.eks.: „,Der kræves i dag så meget af en elitespiller, at lysten ikke alene driver værket." Dertil kommer, at problemstillingen i høj grad har indflydelse på fodboldens samfundsmæssige funktioner - en udvikling mod arbejdslignende former vil jo nok flytte vægten væk fra sundheds/motions/bredde funktionen og over mod underholdningsfunktionen.

Min baggrund for denne hypotese var godt 20 år som spiller på mange forskellige niveauer, et par år som træner, nogle trænerkurser, fodbold som specialefag ved Institut for Idræt Odense Universitet og, da jeg startede på specialet, undervisningsassistent i fodbold samme sted. Men dette var naturligvis ikke vægtigt nok som dokumentation, og da der ikke fandtes ret meget litteratur om emnet, lavede jeg en undersøgelse blandt spillere og trænere.

Trænerundersøgelsen bestod af interviews med Bent Dahl (DBU's konsulent 1969-78), Poul Erik Bech, Tommy Troelsen, Kaj Christensen, Rolf 
Hjernøe, A. P. Jensen og Tage Lausdal - trænere som alle havde virket $i$ mindst 10 år (serie 3 - 1.div.), som alle havde et optimalt træneruddannelsesniveau og som tillige selv havde oplevet udviklingen tilbage fra omkring 1950.

Med hensyn til spillerne brugte jeg spørgeskemaer, og her fik jeg svar fra 78 repræsenterende 10 klubber og nogenlunde fordelt på de forskellige niveauer inden for DBU. De 29 divisions- og danmarksseriespillere havde en gennemsnitsalder på 28 år og dermed et godt grundlag for at vurdere udviklingen fra 68-78.

Statistisk set er undersøgelsen således slet ikke stor nok til, at der kan generaliseres til hele DBU-fodbolden. Alligevel mener jeg, at den giver et rimeligt billede af udviklingen, specielt inden for dansk topfodbold fra 68-78. Trænerrotationen mellem klubberne, den fælles træneruddannelse og turnering giver nemlig en tendens til ens aktivitet $i$ klubberne. Selv om en noget større undersøgelse selvfølgelig havde været at foretrække er mit materiale i hvert fald langt mere pålideligt end de ofte anvendte (én mands vurderings-) litteraturkilder.

I den følgende gennemgang af udviklingen $i$ forhold til leg-arbejde vil jeg dele aktiviteten op $\mathrm{i}:$ 1) Træningen, herunder trænergerningen og selve træningen, og 2) Spillet/kampene. Da det inden for disse rammer desværre ikke er muligt at give belæg for alle konklusioner, har jeg valgt at dokumentere nogle enkelte udvalgte og for andres vedkommende blot nævnt konklusionerne.

Derefter vil jeg se på fodbold- og samfundsmæssige årsager til udviklingen og til slut gøre nogle betragtninger over konsekvenserne.

\section{Fodboldens udvikling i forhold til leg-arbejde}

\section{A. Træner,,gerningen"/,jobbet"- idealistisk fritidsbeskæftigelse og/eller profession?}

I henhold til den norske sociolog Ulf Thorgersen kan man sige, at trænergerningen har undergået en professionalisering hvis der er tale om et forhøjet uddannelsesniveau, en højere aflønning samt en tættere kobling mellem uddannelse og erhverv - og det er netop hvad der er sket inden for DBU $i$ denne periode. For elitens vedkommende er alle 3 punkter opfyldt, mens professionaliseringen af trænergerningen for breddens vedkommende stort set har været begrænset til et forbedret træneruddannelsesniveau. 


\section{1.b. Træningen.}

Det følgende er direkte citat fra specialet, og jeg må derfor minde om, at det er skrevet for 5 år siden.

Med hensyn til perioden før 1950 er den konklusion, jeg kan uddrage af trænerundersøgelsen, at træningen her udviklede sig meget lidt. Groft sagt bestod den af lidt fysisk træning i form af nogle løbeture rundt om banen, resten var spil til to mål. I løbet af de næste 15-20 år blev træningen efterhånden mere struktureret og planlagt. Dette gjaldt også den fysiske træning, som fik en lidt større vægt. Men i forhold til de sidste 10-15 år virker denne udvikling nærmest som en skildpadde mod en OL-sprinter. Alle trænerne er enige om, at den seneste udvikling er noget for sig.

Spillerundersøgelsens resultater med hensyn til træningens udvikling fremgår af tabel 5. I spm. 1 har jeg operationaliseret det kvantitative, i spm. 1, 2 og 4 det rationelt forberedende/eksternt målrettede (ifølge trænerundersøgelsen er træningsmængde og konditionstræning direkte rettet mod kampresultater).

Ud fra spm.1, 2 og 4 tegner der sig et helt klart billede: træningsmængden er blevet forøget, konditionstræningen er blevet hårdere og træningen er blevet bedre som kampforberedende aktivitet. Svarene på spm.3 viser, at dette ikke blot skyldes overgangen til pengefodbold. Det ser ud til, at udviklingen m.h.t. træningsmængde og konditionstræning fra 77-78 blot har været lidt stærkere end i de foregående år.

Med hensyn til træningsmængden bekræftes dette af en undersøgelse, som blev lavet i foråret 78. I undersøgelsen, som bygger på svar fra 29 divisionsklubber, siges herom:

„Så meget træner divisionsklubberne i turneringsperioden i en uge, hvor der kun spilles Weekend-kampe:

En enkelt klub nøjes med 2 træningsaftener, hovedparten træner 3 gange, en del 4 gange og en enkelt klub 5 gange om ugen.

Det er mit indtryk, at der generelt er sket en mindre optrapning af træningen i forhold til 1977, måske specielt i optræningsperioden jan., feb., marts." 1

Den udvikling, som fremgår af spm.1, 2 og 4 bekræftes fuldt ud af trænerundersøgelsen, som i øvrigt tyder på, at opskruningen af træningsmængden specielt er foregået de sidste 4-5 år. Desuden fremgår det, at den

1. Knud Nørregård (divisionsspiller fra Vejle):

„Undersøgelse over betalt fodbold i Danmark 1978“, s. 9, (idrætssociologi-opgave ved Institut for Legemsøvelser, OU). 
Tabel 5. Træningens udvikling inden for dansk topfodbold, ca. 1967-78.

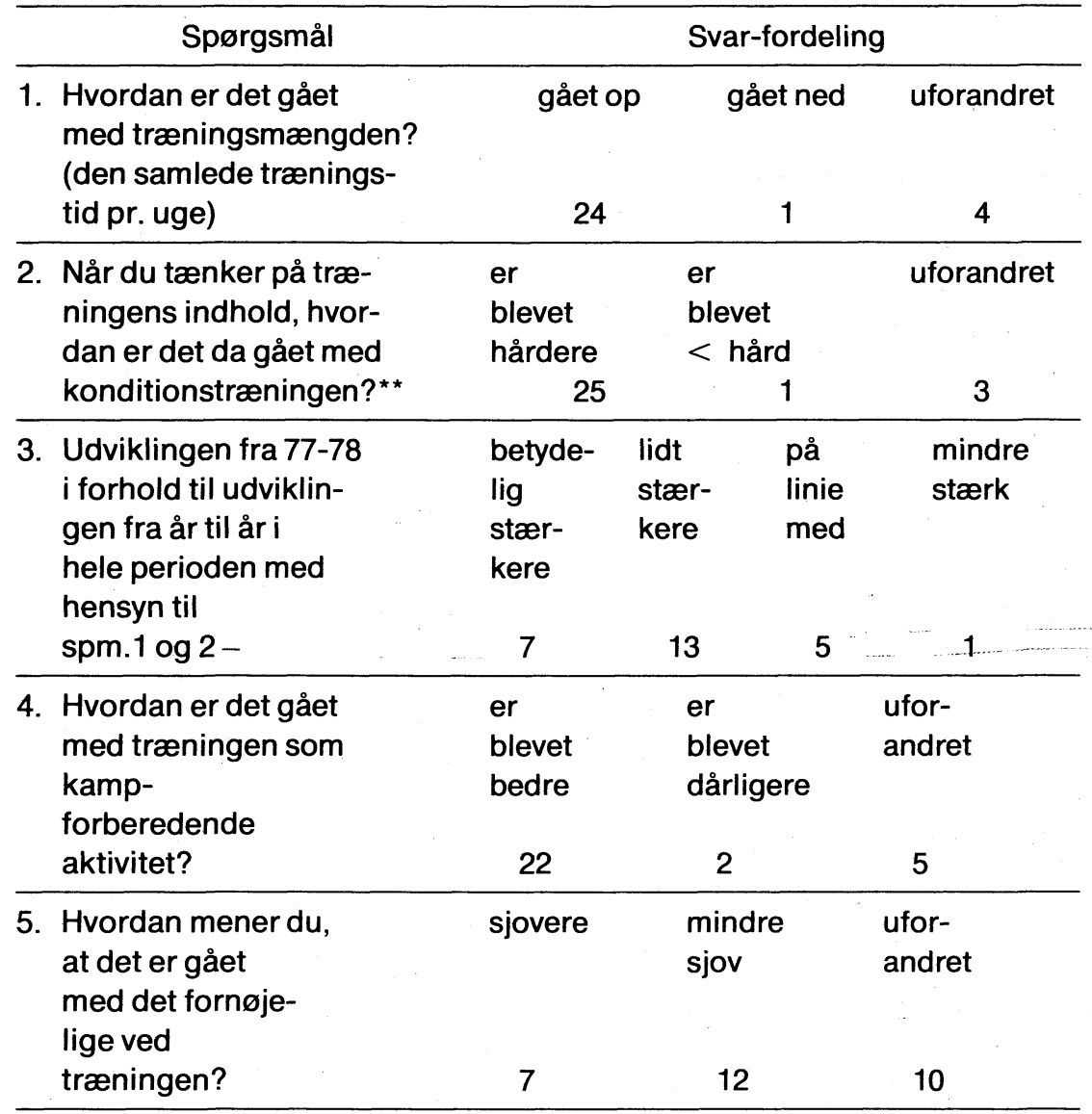

Anmærkninger: $\mathrm{N}=29$

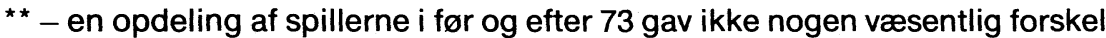
m.h.t. spm. 1 og 2.

fysiske træning/konditionstræningen også har fået en betydelig større plads, rent tidsmæssigt, i træningen.

Ud over træningens udvikling har jeg bedt om spillernes holdning til træningen med henblik på at bestemme denne $\mathrm{i}$ forhold til leg-arbejde. Svarene fremgår af tabel 6. 
Tabel 6. Elitespillernes holdning til træningen.

\begin{tabular}{|c|c|c|c|c|}
\hline \multicolumn{2}{|r|}{ Spørgsmål } & \multicolumn{3}{|c|}{ Svar-fordeling } \\
\hline 1. & $\begin{array}{l}\text { Mener du, at træningen } \\
\text { i } 75-76 \text { af og til var } \\
\text { „et kedeligt og uinter- } \\
\text { essant slid"“?** }\end{array}$ & ja & delvis & nej \\
\hline \multicolumn{5}{|c|}{$\begin{array}{l}\text { 2. Som spiller kan man principielt have to forskellige opfattelser af trænin- } \\
\text { gens formål: } \\
\text { a) Træningen kan være noget man går til for sin fornøjelses skyld - for at } \\
\text { spille noget fodbold og være sammen med kammerater - og samtidig } \\
\text { få noget motion. } \\
\text { b) Træningen kan være noget man går til, fordi det gør holdet og én selv } \\
\text { bedre i kampene, og fordi det er en forudsætning for at komme på hold. }\end{array}$} \\
\hline 2.1. & $\begin{array}{l}\text { med træningen } i \\
\text { forhold til } \\
\text { a) og b)? } \\
\text { amatører }\end{array}$ & som a) & som b) & $\begin{array}{l}\text { både som } \\
\text { a) b) }\end{array}$ \\
\hline & kontraktspillere & 1 & 4 & 19 \\
\hline & i alt & 9 & 7 & 23 \\
\hline \multirow[t]{3}{*}{2.2 . } & $\begin{array}{l}\text { Hvad er vigtigst for } \\
\text { dig af de to formål!* } \\
\text { amatører }\end{array}$ & 2 & & 3 \\
\hline & kontraktspillere & 7 & 7 & 10 \\
\hline & i alt & 9 & 7 & 13 \\
\hline
\end{tabular}

* - de 2 ,,som a)" og de 4 ,,som b) “ fra 2.1 er inkluderet.

** - citat fra DBU-betænkning i 1976.

En hel eller delvis bekræftelse på spm.1 har jeg taget som et udtryk for, at dele af træningen minder mere om arbejde end leg (,slid" - glæde og spænding er fraværende). I spm.2 er a) en operationalisering af det fornøjelige/fravær af eksterne mål (strengt taget er motion et eksternt mål, men det er forskelligt fra det kamp-rettede), b) af ekstern målretning/det rationelt forberedende.

Selv om et lille flertal afviser det ,,kedelige og uinteressante slid" må man nok sige, at spm. 1 og i mindre grad spm.2, sammen med spm. 5 i tabel 5 , sætter et betydeligt spørgsmålstegn ved dansk topfodbold som en lystbeto- 
net fritidsbeskæftigelse. Spm. 2 i tabel 6 viser dog, at det fornøjelige, sociale og sundhedsmæssige for spillerne er meget væsentlige motiver for at gå til fodboldtræning. Det har omtrent samme prioritet som det kampforberedende motiv. Med hensyn til prioriteringen mellem de to motiver er der en tydelig forskel på amatører og kontraktspillere. Sidstnævnte har en helt ligelig fordeling, amatørerne klar overvægt til motiv a). Nu kan man jo ikke generalisere ud fra 5 spillere (amatører er ret sjældne); men resultat bekræfter $\mathrm{i}$ det mindste den motivationsforskel mellem amatører og halvprofessionelle, som man kunne forvente.

For bedre at kunne relatere til problemstillingen leg-arbejde har jeg bedt spillerne begrunde deres svar på spm. $5 \mathrm{i}$ tabel $5 \mathrm{og}$ spm. $1 \mathrm{i}$ tabel 6 . Dertil har jeg anvendt helt åbne spørgsmål. Med hensyn til det fornøjelige ved træningen var den mest udprægede holdning jo, at træningen er blevet mindre sjov. Det er da også den opfattelse, som er blevet grundigst motiveret. Af de i alt 26 begrundelser for ",mindre sjov" (hver spiller har op til 3 begrundelser) går de 22 på, at træningen er blevet mere alvorlig/eksternt målrettet/rationelt forberedende. Som én af spillerne udtrykker det: ,,Efterhånden tolereres der ikke skæg og ballade spillerne/trænerne imellem, der kræves at man tager det yderst alvorligt hele tiden". Kun 4 af disse 22 begrunder udviklingen med indførelsen af betalt fodbold.

Sammen med begrundelserne for spm. 1 i tabel 6 tyder dette stærkt på, at den forøgede træningsmængde, den hårdere konditionstræning og - i sammenhæng hermed - den mere målrettede træning har hovedansvaret for, at træningen for så mange spillere er blevet mindre fornøjelig og til tider nærmest har været et ,,kedeligt og uinteressant slid".

Alt $i$ alt tyder materialet altså stærkt på, at min hypotese har været rigtig for elitens vedkommende; men hvad med de øvrige spilleniveauer?

\section{Bredden, ungdommen}

Her er mit materiale igen trænerundersøgelsen samt en spillerundersøgelse. Med hensyn til ungdommen bygger jeg udelukkende på trænernes vurderinger, spillerundersøgelsen er begrænset til seniores (seriespillere). Da jeg ikke har kunnet finde tilstrækkelig mange spillere med 5-10 års seniorerfaring, har jeg brugt en lidt anderledes metode end ved eliten. Jeg har spurgt om udviklingen fra ynglingetiden til undersøgelsestidspunktet. Da ynglingetræningen også har udviklet sig, og ikke er ens for højere og lavere rangerende hold, er konklusionerne af en sådan udvikling ret problematiske. Dog mener jeg, at de kan tjene som en understøttelse af trænernes vurderinger.

For seriespillerne under ét viser svarene, at træningsmængden og kondi- 
tionstræningens intensitet ikke har forandret sig væsentligt fra ynglinge- til seniortiden. Men når man skelner mellem højere og lavere rangerende spillere, får man et ret tydeligt billede. For spillerne fra serie 1-3 er der tendens til forøget træningsmængde, og det er helt tydeligt, at konditionstræningen er blevet mere intensiv. Hos serie 4-6 spillerne derimod er der klar tendens til en mindre træningsmængde og samtidig mindre hård konditionstræning.

For de øverste seriers vedkommende støtter denne udvikling trænernes vurdering, som går på, at konditionstræningen gennem de sidste 10 år er blevet mere intensiv og omfattende, og at der på det sidste også er tendenser til forøget træningsmængde.

Dette støttes igen af DM-spillerne. På spørgsmålet, om der m.h.t. træningsmængden og konditionstræningens intensitet har været en tilsvarende udvikling på serie 1-2 niveau, har 10 svaret helt eller delvis bekræftende, 3 nej og 13 ved ikke.

I de lavere serier er trænernes vurdering, at der er sket en begrænset opskruning af den fysiske træning, men ikke nogen forøgelse af træningsmængden.

Desuden er træningen generelt, men specielt $\mathrm{i}$ de øverste serier, blevet mere planlagt og kvalificeret med henblik på forberedelse til kampene, altså mere målrettet.

Inden for ungdomsfodbolden har der for de bedste hold været en udvikling af samme art som i de øverste serier. Dette gælder specielt junior- og ynglingehold, hvor man bevidst søger gradvis at tilpasse træningen til seniorniveauet. Men også blandt de lavere rangerende hold, og helt ned til puslingene, er man begyndt at satse mere på den fysiske træning. Flere af trænerne mener, at man $i$ en del klubber overdriver konditionstræningen med drengespillere.

Noget der specielt gør sig gældende inden for ungdomsfodbold er tendenser til en mere planlagt og fast struktur. I mange klubber er man begyndt at lave ret omfattende beskrivelser af aktivitetens mål og indhold i de forskellige aldersgrupper.

For at bestemme seriespillernes holdning til træningen m.h.t. leg-arbejde stillede jeg dem de samme spørgsmål som DM-spillerne:

Svarene på spm.1 viser, at seriespillerne generelt har samme indstilling som eliten. Et lille flertal afviser helt det „kedelige og uinteressante slid", de øvrige svarer mest delvis bekræftende. Men når man niveaudeler, viser der sig en markant forskel. Blandt de højere rangerende spillere er der klar overvægt til ja eller delvis, blandt de lavere rangerende lige så klart overvægt til nej. 
Tabel 8. Seriespillernes holdning til træningen.

\begin{tabular}{|c|c|c|c|}
\hline \multirow{5}{*}{\begin{tabular}{l}
\multicolumn{1}{c}{ Spørgsmål } \\
1. Har den træning, du har \\
gået til som senior, af \\
og til været et ,,kedeligt \\
og uinteressant slid“? \\
serie 1-3 \\
serie 4-6 \\
total $^{*}$
\end{tabular}} & \multicolumn{3}{|c|}{ Svar-fordeling } \\
\hline & ja & delvis & nej \\
\hline & 7 & 11 & 7 \\
\hline & 1 & 5 & 17 \\
\hline & 8 & 16 & 26 \\
\hline $\begin{array}{l}\text { 2. Hvad er dit formål med } \\
\text { træningen i forhold til } \\
\text { a) og b)? (jvf. tabel 6) }\end{array}$ & som a) & som b) & $\begin{array}{c}\text { både } \\
\text { som a) } \\
\text { og b) }\end{array}$ \\
\hline serie $1-3$ & - & 2 & 21 \\
\hline serie $4-6$ & 2 & 2 & 18 \\
\hline total & 2 & 4 & 41 \\
\hline \multicolumn{4}{|l|}{$\begin{array}{l}\text { 3. Hvad er vigtigst for dig } \\
\text { af de to formål? }\end{array}$} \\
\hline serie $1-3$ & 4 & 2 & 17 \\
\hline serie 4-6 & 11 & 2 & 9 \\
\hline total & 15 & 4 & 28 \\
\hline
\end{tabular}

Ligesom ved DM-spillerne har jeg efterlyst de ting ved træningen som gjorde, at den somme tider var et kedeligt og uinteressant slid. Svarene gav et meget interessant billede. For serie 1-3 spillerne faldt 24 af de $i$ alt 28 svar $i$ to lige store kategorier:

1) den målrettede-, specielt fysiske træning.

2) utilfredshed med trænerens kvalifikationer og dermed træningens kvalitet.

Sammenlignet med DM-spillerne er 1) lige så væsentlig en begrundelse, 2) derimod er klart mere fremtrædende hos spillerne fra serie 1-3.

Hos de lavest rangerende spillere var svarene af en noget anden karakter. Kun én angav 1) som årsag. De øvrige 10 gik alle på dårlige forhold ${ }^{2}-5$ på 2), 3 på for mange spillere pr. træner (op til 40, til tider slet ingen træner), én: ",for lang ventetid, for få bolde“.

2. - og kom i øvrigt alle fra de tre divisionsklubber. 
Svarene tyder altså på, at den effektive og målrettede træning, af og til forbundet med direkte ulyst hos spillerne, er ret fremtrædende i de øverste serier. I de laveste serier derimod er denne form for træning meget sjælden.

Spm.3 i tabel 8 bekræfter til dels dette billede. For de øverst rangerende spillere er det kampforberedende formål med træningen omtrent lige så vigtigt som det sociale-, sundhedsmæssige- og lystbetonede formål. For de lavest rangerende spillere derimod er kampforberedelsen et mindre vigtigt formål med træningen.

Sammenholdes dette med trænernes vurdering af udviklingen, tyder det på, at træningen gennem de sidste 10-15 år også i de øverste serier har bevæget sig bort fra leg og hen imod arbejdslignende former. Hvis ungdomsspillernes holdning til træningen svarer til seniorspillernes, er det samme tilfældet i de øverste junior- og ynglingerækker. I de laveste serier derimod kan der ikke konstateres en sådan udvikling. Hvis der er en forøget ekstern målretning, er den meget begrænset, og den forbindes i hvert fald ikke med ulyst. Aktiviteten for aktivitetens egen skyld er klart mere fremtrædende. Spillerundersøgelsen tyder altså stærkt på, at der med hensyn til leg-arbejde er al mulig grund til at skelne mellem forskellige spilleniveauer, specielt mellem DM (= divisionerne og danmarksserien)/mellem-niveauet og de laveste serier.

Det vil sige at elitefodboldens afsmitning på bredden nok er en sandhed med kraftige modifikationer. Det er mit indtryk, at bredde/motions-modellen (,,alkohold“", lukkede hold m.m.) trives i bedste velgående i de lavere serier; men at elitepåvirkningen - i den udstrækning der findes ambitiøse trænere, ledere og spillere - også når ned til denne bredde. Heraf følger også, at afsmitningen er tydeligst i de højeste serier og inden for ungdomsfodbolden, jfr. trænernes bekymring for konditionstræningen her.

\section{Spillet/kampene.}

Kort fortalt var udviklingen for elitens vedkommende, at konditionen helt tydeligt fik en større betydning i kampene, at trænerens taktiske vejledning op til kampene blev mere omfattende, og at den enkelte spiller efterhånden fik flere bundne opgaver. Spillernes svar tyder på, at det kvalitative improvisationerne, det tekniske, ,lækkerierne“ - gik tilbage på grund- og bekostning af det kvantitative (fysikken, som er et spørgsmål om træningsindsats/træningsmængde) samt det fast strukturerede og resultatorienterede.

Med hensyn til bredden/ungdommen er billedet som under træningen: I de øverste serier og ungdomsrækker overtog man stort set elitens udvikling. I 
de lavere rækker begyndte man godt nok også at spille 4:3:3; men ikke med det samme fysiske og taktiske indhold.

I øvrigt understøttede resultaterne her i høj grad konklusionerne med hensyn til træningens udvikling.

\section{Konklusion}

Alt i alt tyder mit materiale stærkt på, at DBU-fodbolden - bortset fra de laveste serier og ungdomsrækker - i perioden bevægede sig bort fra legen og mod arbejdslignende former. Dette gjaldt såvel trænergerningens professionalisering som træningens og spillets udvikling, og udviklingen var tydeligst for elitens vedkommende.

Fodbolden nærmede sig altså i den forstand det øvrige samfund; men hvordan gik det egentlig til?

\section{Udviklingens årsager}

Umiddelbart er det vigtigste nok den indflydelse, som de førende udenlandske hold har haft. I konkurrencen med disse er danske divisions- og landsholdsspillere gang på gang kommet til kort, først og fremmest på grund af forskellen i fysisk formåen. Hvis man ville klare sig i konkurrencen - og det ville man, klub- og nationalfølelsen er åbenbar i så henseende - var man altså nødt til at tage ved lære af disse holds træning og spil. ${ }^{3}$

At man ret let kunne gøre dette hænger sammen med, at DBU m.h.t. træneruddannelse har fået et ret tæt samarbejde med andre lande. Omstruktureringen i 70'erne var blandt andet inspireret af dette samarbejde. ${ }^{3}$ En nyskabelse i træningen, som direkte importeredes fra udlandet, var f.eks., at man begyndte med kun ét hold pr. træner ${ }^{4}$.

Denne udenlandske påvirkning var uden tvivl den væsentligste direkte årsag til udviklingen. Men der er tilsyneladende også en dybere baggrund.

De omtalte udenlandske hold er naturligvis de professionelle. Professionalismen er imidlertid ikke nogen forklaring i sig selv. Professionel fodbold har snart 100 års fødselsdag i England, og i 20'erne havde den bredt sig til mange andre lande ${ }^{5}$. Opskruningen af tempoet/den fysiske træning er imidlertid

3. - trænerundersøgelsen.

4. Kaj Christensen. Hermed være dog ikke sagt, at DBU's træneruddannelse er en kopi af det udenlandske. M.h.t. det pædagogiske og ungdomsfodbolden indtager den en prisværdig særstilling (træneruddannelsen; jvf. også: DBU: „Mini-fodbold i skolen").

5. DBU-75 op cit, s. 35-36. 
først rigtig kommet de sidst 20-25 år6. Og der er ingen tvivl om, at årsagen hertil ligger i den videnskabelige udvikling.

Netop i denne periode er den idrætsfysiologiske forskning nemlig slået igennem ${ }^{7}$, og i dag bygger den fysiske træning i høj grad på et videnskabeligt grundlag ${ }^{8}$. Med de nye videnskabelige landvindinger i baghovedet har trænerne opprioriteret og effektiviseret den fysiske træning. Når det først slog igennem i de professionelle klubber, skyldtes det naturligvis toptrænerne, samt at spillerne her havde den tilstrækkelige tid og desuden den indirekte motivation.

At dansk fodbold ret hurtigt tilnærmede sig den internationale udvikling har nok også en bredere baggrund. Midt i 50'erne havde man i DBU's træneruddannelse stadigvæk ikke opgivet det 2-back system, som engelsk fodbold næsten 30 år tidligere havde forladt ${ }^{9}$. Da England i 1966 introducerede 4:3:3, blev det derimod kopieret af dansk fodbold $i$ løbet af 5-7 år. Men hvad er der da sket i mellemtiden?

I 1954 blev Union des Associations Européenes de Football (UEFA) stiftet, og derefter er europæisk fodbold i stigende grad blevet integreret ${ }^{10}$. Hvor langt integrationen er kommet, illustreres af, at der sikkert dannes en europæisk trænersammenslutning her i $80^{11}$. Sammenfaldet med den markedspolitiske integration ${ }^{12}$ er så udpræget, at det næppe er nogen tilfældighed (EF's udvidelse i 72 blev da også markeret med en fodboldkamp). Ligesom den generelle integration var den fodboldsmæssige bl.a. betinget af den transportteknologiske udvikling ${ }^{13}$; men også en anden teknologisk nyskabelse var meget vigtig: Herhjemme slog TV-transmission af europæiske topkampe netop igennem i $60^{\prime}$ erne $^{14}$, specielt i den sidste halvdel ${ }^{15}$. Transmissionen af de engelske tipskampe startede i $69^{16}$.

Sammen med den europæiske integration er TV-fodbolden utvivlsomt den væsentligste årsag til den hurtigere overførsel af nye spilleformer.

Min konklusion på disse betragtninger bliver da, at den beskrevne udvikling mod arbejdslignende former først og fremmest har sat sig igennem via

6. Trænerundersøgelsen, specielt Kaj Christensen om tysk fodbolds udvikling.

7. Mc Intosh s. 131-32; Åstrand \& Rodahl: Textbook of Work Physiology, (,,references")

8. se f.eks. Gøran Agnevik: Fotboll.

9. Niels Middelbo op cit; Bent Dahl.

10. Idorn op cit, s. 29-109.

11. A. P. Jensen.

12. Tovo Miljan: The Reluctant Europeans.

13. $D B U-75$, s. 152-53.

14. Gunnar (Nu) Hansen i DBU-75, s. 132-35.

15. Trænerundersøgelsen.

16. „,Sports/ørdag“, d. 15/2-79. 
videnskabelig udvikling, udenlandsk professionalisme, TV og europæisk integration.

$\mathrm{Da}$ de 3 sidstnæunte faktorer var nogle af de umiddelbare årsager til indførelsen af betalt fodbold, bliver de det nu i dobbelt forstand: De betød nemlig også, at danske divisionsspillere så småt begyndte at træne professionelt, og at deres ønske om en aflønning derfor forekom rimeligt.

\section{Afs/uttende bemærkninger}

Med hensyn til fodboldens samfundsmæssige funktioner frem til i dag ser det ud til, at professionaliseringen - forstået som udviklingen mod arbejdslignende former i sammenhæng med indførelsen af betalt fodbold - har haft en gavnlig indvirkning på underholdningsværdien. Det ser godt nok stadig væk sløjt ud med tilskuertallene; men der er tydelige tegn på, at kvaliteten er blevet bedre.

Men hvad så med den sundhedsmæssige funktion? Denne har jo, i hvert fald hidtil, været den væsentligste motivering for den offentlige støtte-til idrætten. Opfyldelsen heraf er afhængig af hvor mange der dyrker fodbold, og om det sker på sådan en måde, at det giver ,helse for sjæl og krop“. Ud fra mit materiale at dømme var der god grund til at frygte, at disse ting ville komme i fare på grund af professionaliseringen. Frafaldsundersøgelser og min egen undersøgelse tydede nemlig på, at der - samtidig med elitens stimulerende virkning på bredden - i høj grad også er et modsætningsforhold mellem elite/konkurrence-orienteringen og bredden. I dag kunne det se ud til at dette er slået igennem, idet fodbolden i disse landskampsucces år ikke har kunnet fastholde sin andel af den organiserede idrætsudøvelse.

Denne tilsyneladende forskydning mellem spillets samfundsmæssige funktioner er sket parallelt med, at folketinget er blevet langt mere positiv over for støtte til elite/underholdnings-idræt, så der er ingen problemer med den offentlige støtte. Men samtidig har DIF stadig tydeligere vedkendt sig bredde/sundheds-formålet, og derfor mener jeg, at der er behov for en nærmere undersøgelse af problemstillingen - også fordi vi lever i en tid med store ungdomsproblemer, og derfor må det være vigtigt at fodbolden så godt som muligt lever op til den forpligtigelse om at ,,vedkende sig opdragende, pædagogiske og udviklende opgaver over for mennesker", som dansk idræt allerede i betænkningen fra 1976 påtog sig at arbejde for. 